\title{
QUANTITATIVE EVALUATION OF PROSPECTIVE TEACHERS' VIEWS ON INCLUSIVE EDUCATION
}

\author{
Suat Turkoguz ${ }^{1}$, \\ Muhammet S. Baran', \\ Mehmet Gurbuz ${ }^{2}$, \\ Cengiz Tuysuz ${ }^{2}$, \\ Ilker Ugulu ${ }^{2 \mathrm{i}}$ \\ ${ }^{1}$ Buca Faculty of Education, \\ Dokuz Eylul University, \\ Izmir, Turkey \\ ${ }^{2}$ Faculty of Education, \\ Usak University, \\ Usak, Turkey
}

\begin{abstract}
:
In this study, pre-service teachers' views on inclusive education were evaluated from a quantitative research perspective. The survey model, one of the quantitative research designs, was used. The sample of the study consists of 482 prospective teachers studying at the same state university. The "Opinions Related to Mainstreaming Scale" was used to evaluate the views of pre-service teachers about inclusion. In the study, frequency and percentage values for each item were calculated for the data obtained from the study. In addition, Pearson correlation coefficient was calculated to determine whether there was a relationship between the sub-dimensions of the scale depending on the data collected. Although the results of the research are generally positive, the opinions of the pre-service teachers about inclusive education are inconsistent with each other, indicating that the knowledge and skill levels of the pre-service teachers about students with special needs are insufficient. It is important for a qualified inclusive education that teacher candidates who will start working in schools in the future develop positive attitudes towards inclusive education and have high levels of knowledge and skills.
\end{abstract}

Keywords: special education, inclusive education, teacher candidates

\section{Introduction}

Inclusive education is defined as the students with special needs and normal development receive education within the scope of general education classes. According

${ }^{i}$ Correspondence: email ilkerugulu@gmail.com 
to a more comprehensive definition, inclusive education can be defined as the inclusion of all children and young people in education regardless of individual differences such as race, ethnicity, disability, gender, sexual orientation, language or socioeconomic status (Ewing, Monsen, \& Kielblock, 2017). Within the framework of educational policies and practices, it is possible for individuals with special needs and individuals with normal development to have equal opportunities in education and receive education in the same environment with their peers (Cankaya \& Korkmaz, 2012). With inclusive education, students with special needs can interact and communicate with their peers, develop friendship relations, learn to work together, and help each other by seeing their weaknesses and strengths (Batu, Kurcaali-İftar, \& Uzuner, 2004).

In order for inclusive education to be successful, classroom teachers and school staff should believe in the necessity of inclusive education practice, make an effort in this regard, students with normal development should be informed about special needs students (Orel, Zerey, \& Toret, 2004). In addition to the fact that inclusive education practices require elements such as systematic planning, adequate research, organization of physical environments, and individualized education programs, the experiences of special education teachers, their approaches to the subject and the positive attitudes of students' parents also affect the success of inclusive education practices (Bozarslan \& Batu, 2014). Inclusive education practices are a principled education approach that includes the process of increasing students' exclusion from the curriculum, culture and communities in schools. Inclusive education practices should be restructured according to the culture and policies of schools and the diversity of students in their regions, and the existence, participation and success of all students who are vulnerable to exclusionary pressures should be taken into account, not only individuals with special needs (Ainscow \& Miles, 2008).

Inclusive education practices started to be implemented in many countries in the 1960s. These practices have been launched for the first time in Turkey in 1983 with the Law of Children in Need of Special Education. Afterwards, inclusive education started to be implemented more widely with the "Decree-Law No. 573 on Special Education" in 1997 and the "Special Education Services Regulation" that entered into force in 2000 (Yazicioglu, 2018).

The inclusive education models implemented in Turkey are full-time, part-time and reverse inclusive education models (Yazicıoglu, 2018).

In the full-time mainstreaming practice, individuals with special education needs are provided with education in the same class and socially integrated with their peers in pre-school, primary, secondary and non-formal education institutions. In the part-time mainstreaming practice, necessary arrangements are made for the students who do not receive education in the classrooms where the mainstreaming practice is applied or in the special education classrooms, to participate in the activities of the special education classrooms, and to receive support education from the guidance and research center and the private education institution (Sart et al., 2004). In reverse inclusion, students who do not have special needs enroll in special education schools around them, especially in pre- 
school education, in line with their wishes, and receive education together with individuals with special needs (Topcu \& Katmis, 2013).

Research shows that teachers' perceptions of inclusive education greatly influence both the way they manage their classroom environment and how they understand and interpret the support offered to them. It is seen that special educators who have more responsibilities are more willing to adopt practices that include children with social, emotional and behavioral difficulties (Hind, Larkin, \& Dunn, 2019). Avramidis, Bayliss, and Burden (2000) determined that teachers who implement inclusion programs and therefore have active inclusion experience have more positive attitudes. In addition, the importance of professional development in the formation of positive attitudes towards inclusion has been demonstrated. It has been revealed that teachers with universitybased professional development both have more positive attitudes and are more confident in meeting the individualized education program needs of students with special education needs.

Al-Zyoudi (2006) showed that teachers' attitudes towards inclusion are strongly influenced by the nature and severity of the restrictive situation presented to them, the length of teaching experience, and education. In a different study conducted with classroom teachers experienced in inclusive education, disagreements emerged that both supported and not supported inclusive education. While the reasons for supporting inclusive education were listed as "humanistic thoughts, benefiting status of other students and social reality", the reasons for not supporting inclusive education were determined as "negative influence of other students, not being able to spare time, not getting down to their level, the effect of new education programs" (Demir \& Açar, 2011). Teachers with experience in inclusive education have more positive attitudes than those with less experience, and the smaller the class size, the more positive the attitudes of teachers (De Boer, Pijl, \& Minnaert, 2011). However, as a result of a meta-analysis, it was shown that the problems and negativities related to inclusive education were discussed in general in graduate studies in Turkey (Gurgur \& Yazcayir, 2019). As seen in the literature, it has been observed that there are many studies on the views of teachers on inclusive education, but the studies on the opinions of pre-service teachers are very limited.

Attitudes of pre-service teachers are an indicator of whether inclusive education practices are implemented successfully or not (Ediyanto, Atika, \& Kawai, 2020). In a study examining the attitudes of pre-service teachers towards inclusive education, it was determined that taking inclusive courses had a positive effect on the views of pre-service teachers towards inclusive education (Orel, Zerey, \& Töret, 2004). In a similar study, it was examined whether participation in inclusive education led to statistically significant changes in attitudes among teacher candidates. According to the findings of the study, students who graduated from the special education field were given an extra year of inclusive education and attitude changes were determined in five areas. These are the general attitude about the inclusion skill perceived by the educator, the attitude towards the behavior of the children with special needs, the attitude towards the children with special needs themselves; attitude towards the social and emotional development of children with special needs, and the general attitude towards inclusion. All of these 
attitude levels are more positive in teacher candidates who receive inclusive education compared to other graduates (Killoran, Woronko, \& Zaretsky, 2014).

Al Mahdi and Bukamal (2019) revealed that pre-service teachers need more opportunities to interact and teach with children with special needs during their school internships. In addition, it has been determined that they need more preparation and information about education policies for children with special needs. Not all pre-service teachers trust their knowledge and skills when dealing with these children, but their feelings are generally positive and compassionate towards students. Although the general attitudes of teacher candidates towards inclusion are positive, they have concerns about the inclusion of children with special needs, who show aggressive behavior towards children with normal development or who need communication technologies, in regular classes. In the study conducted by Ediyanto, Atika, and Kawai (2020), it was determined that teacher candidates' supportive attitudes and beliefs towards inclusive education were at the low-medium level. In the study, it was also determined that the thoughts towards inclusion did not differ according to the gender of the pre-service teachers and their experience of inclusion.

Significant findings were obtained in a study in which the opinions of special education teacher candidates working in primary and secondary education were compared. In the answers given by the special education group in primary education, it was stated that inclusion would encourage children's independence, support the integration of students with special needs and other students into the classrooms, encourage understanding of differences between students, and give students with special needs a chance to easily integrate into society. In addition, it was determined that preservice teachers, as teachers, are willing to receive extra education in order to better manage children with special needs in their classrooms, they believe that inclusion is an appropriate educational practice and that most of the students with special needs (regardless of disability level) can be educated in normal classrooms (McHatton \& McCray, 2007).

In a recent study conducted in Turkey, it has been shown that there is a significant difference in terms of attitudes, anxiety and feelings of teacher candidates regarding interdepartmental inclusion, and their confidence levels in teaching students with special needs (Avsar-Tuncay \& Kizilaslan, 2021). It was found that pre-school teacher candidates had more positive attitudes towards inclusion. The findings revealed that pre-service teachers need more opportunities to interact and teach with students with special needs during their school internships. In addition, it was determined that teacher candidates should have experience and self-confidence, as well as have knowledge about legislation and policies related to inclusive education (Avsar-Tuncay and Kizilaslan, 2021). Again, in a study conducted in Turkey, significant differences of opinion on inclusive education emerged as a result of the research carried out with pre-school senior, second- and firstyear students at Bogazici University. Pre-service teachers displayed more positive attitudes towards inclusive education after taking special education courses. However, it has been shown that special education courses do not make a difference in terms of concerns about inclusive education among prospective teachers (Ince, 2012). 
Since the characteristics of teachers and pre-service teachers in a country or region are important in terms of the quality and quality of education, many studies have been and continue to be made on this subject (Avramidis, Bayliss \& Burden, 2000; Al-Zyoudi, 2006; Yorek et al., 2010; Ugulu, 2013; Ugulu, Akkaya \& Erkol, 2013; Ugulu \& Erkol, 2013; Ugulu, Sahin \& Baslar, 2013; Erkol \& Ugulu, 2014; Unal \& Saban, 2014; Aydin et al., 2015; Ugulu, Yorek \& Baslar, 2015; Yorek et al., 2016; Hind, Larkin \& Dunn, 2019; Ugulu, 2019; Ediyanto, Atika \& Kawai, 2020; Ugulu, 2020; Avsar-Tuncay \& Kizilaslan, 2021; Tuysuz \& Ugulu, 2021; Ugulu, 2021a, b). In this study, pre-service teachers' views on inclusive education were evaluated from a quantitative research perspective.

\section{Material and Methods}

\subsection{Research Design}

In this study, the survey model, one of the quantitative research designs, was used. Survey model is a research approach that aims to define a past or present situation as it exists. In this model, there is no effort to change or influence whatever is the subject of research. The aim of this method is to search for answers to the questions of what is the current state of the event or problem that is desired to be investigated with field scanning (Yorek et al. 2008; Koruoglu et al., 2015).

\subsection{Sampling}

The research universe consists of the $2 \mathrm{nd}$, 3rd and 4th-year students of a state university in Turkey. As it was thought that it was difficult to reach all of the students within the scope of the study, sampling was chosen. The sample of the study consists of 482 prospective teachers studying at the same state university. The sampling was created using the convenience sampling method among non-random sampling methods (Fraenkel \& Wallen, 2006; Ugulu, 2015a, b). In the convenience sampling method, the researcher chooses a situation that is close and easy to access. This sampling method brings speed and practicality to the research (Ugulu et al., 2008; Yorek et al., 2010).

\subsection{Data Analysis}

In the study, frequency and percentage values for each item were calculated for the data obtained from the study (Ugulu, 2009; Yorek \& Ugulu, 2015). In addition, Pearson correlation coefficient was calculated to determine whether there was a relationship between the sub-dimensions of the scale depending on the data collected.

\subsection{Data Collection Tool}

In the study, the "Opinions Related to Mainstreaming Scale" was used to evaluate the views of pre-service teachers about inclusion. The Turkish adaptation of the scale developed by Antonak and Larivee (1995) to determine the attitudes of teachers towards the education of students with special needs in general education classes was carried out by Kircaali-Iftar (1996). In the construct validity analysis of the 20 -item scale, it was seen that it consisted of 5 factors. While 8 items $(4,5,7,8,12,14,18,19)$ in the scale are related 
to sub-dimensions (Management of the Inclusion Class) and (Opinions on Inclusion), 3 items $(9,15,17)$ with sub-dimension (Teacher's Competence), and 5 items $(2,3,13,16,20)$ are associated with the (Benefits of Inclusion) sub-dimension, 2 items $(1,6)$ with the (Sufficiency of Disabled Student) and (Benefit of Integration) sub-dimensions, and 2 items $(10,11)$ with the (Negative Effect of Inclusion) sub-dimension.

In the scale consisting of 20 items in total, participants are asked to evaluate themselves on a 4-point Likert-type scale ranging from "1=strongly disagree" to "4=strongly agree". As a result of the analysis of the collected data, the Cronbach alpha internal consistency coefficient was 0.77 for the "Management of the Inclusion Class" subdimension, 0.60 for the "Opinions on Inclusion" sub-dimension, 0.60 for the "Teacher's Competence" sub-dimension, 0.78 for the "Benefits of Inclusion" sub-dimension, 0.71 for the "Negative Effect of Inclusion" sub-dimension, and 0.82 for the whole scale.

\section{Results}

In this study, pre-service teachers' views on inclusive education were evaluated from a quantitative research perspective. For this purpose, the findings obtained with the "Opinions Related to Mainstreaming Scale" are presented in tables in this section.

The data obtained from the analysis made for the "Management of the Inclusion Class" and "Opinions on Inclusion" sub-dimensions of the data collection tool are presented in Table 1. For the expression "Expectations from children with special needs should be different from those expected from children with normal development.", 50.5\% of the students stated "agree" and 38.1\% "strongly agree". 39.5\% of the students stated "agree", 32.9\% "disagree" and 21.4\% "strongly agree" on the item "Children with special needs are generally happier being with children who are similar to them.". $58.1 \%$ of the students stated "agree" and 36.1\% "strongly agree" on the expression "The social interaction provided by inclusion facilitates the understanding and acceptance of differences among students.". 57.6\% of the students said "agree" and 36.3\% "disagree" to the item "Students who need special education are not more likely to show behavior problems in the regular classroom than they will in the segregated classroom.". 51.9\% of the students answered "The comfort in the normal classroom leads to the confusion of the student who needs special education." as "agree" and 33.8\% "disagree". For the item "The inclusion of students with special needs does not contribute to their independence.", $53.3 \%$ of the students answered "disagree" and 30\% "strongly disagree". On the expression "The presence of a student with special needs in the classroom in no way hinders the development of normal children.", 42.4\% of the students stated "agree", $28.6 \%$ "strongly agree" and 26.2\% "disagree". Finally, for the item "The student who needs special education can cause confusion in the regular classroom." $42.9 \%$ of the students answered "agree" and 37.6\% "disagree" (Table 1). 
Table 1: Frequency and percentage values of pre-service teachers' views on "Management of the Inclusion Class" and "Opinions on Inclusion" sub-dimensions

\begin{tabular}{|l|c|c|c|c|c|c|c|c|}
\hline \multirow{2}{*}{ Items } & \multicolumn{2}{|c|}{$\begin{array}{c}\text { Strongly } \\
\text { disagree }\end{array}$} & \multicolumn{2}{|c|}{ Disagree } & \multicolumn{2}{|c|}{ Agree } & \multicolumn{2}{|c|}{$\begin{array}{c}\text { Strongly } \\
\text { agree }\end{array}$} \\
\cline { 2 - 10 } & F & $\%$ & F & $\%$ & F & $\%$ & F & $\%$ \\
\hline $\begin{array}{l}\text { Expectations from children with special needs } \\
\text { should be different from those expected from } \\
\text { children with normal development. }\end{array}$ & 6 & 2,9 & 18 & 8,6 & 106 & 50,5 & 80 & 38,1 \\
\hline $\begin{array}{l}\text { Children with special needs are generally } \\
\text { happier being with children who are similar to } \\
\text { them. }\end{array}$ & 13 & 6,2 & 69 & 32,9 & 83 & 39,5 & 45 & 21,4 \\
\hline $\begin{array}{l}\text { The social interaction provided by inclusion } \\
\text { facilitates the understanding and acceptance of } \\
\text { differences among students. }\end{array}$ & 3 & 1,4 & 9 & 4,3 & 122 & 58,1 & 76 & 36,1 \\
\hline $\begin{array}{l}\text { Students who need special education are not } \\
\text { more likely to show behavior problems in the } \\
\text { regular classroom than they will in the }\end{array}$ & 7 & 3,3 & 72 & 34,3 & 121 & 57,6 & 10 & 4,8 \\
segregated classroom. & & & & & & & & \\
\hline $\begin{array}{l}\text { The comfort in the normal classroom leads to } \\
\text { the confusion of the student who needs special } \\
\text { education. }\end{array}$ & 5 & 2,4 & 71 & 33,8 & 109 & 51,9 & 25 & 11,9 \\
\hline $\begin{array}{l}\text { The inclusion of students with special needs } \\
\text { does not contribute to their independence. }\end{array}$ & 63 & 30,0 & 113 & 53,8 & 26 & 12,4 & 8 & 3,8 \\
\hline $\begin{array}{l}\text { The presence of a student with special needs } \\
\text { in the classroom in no way hinders the } \\
\text { development of normal children. }\end{array}$ & 6 & 2,9 & 55 & 26,2 & 89 & 42,4 & 60 & 28,6 \\
\hline $\begin{array}{l}\text { The student who needs special education can } \\
\text { cause confusion in the regular classroom. }\end{array}$ & 23 & 11,0 & 79 & 37,6 & 90 & 42,9 & 18 & 8,6 \\
\hline
\end{tabular}

The data obtained from the analysis made for the "Teacher's Competence" subdimension of the data collection tool are presented in Table 2. For the expression "Special attention given to the student who needs special education in the regular classroom will be to the detriment of other students.", $48.1 \%$ of the students stated "disagree" and 30.5\% "agree". $41 \%$ of the students stated "agree" and $37.6 \%$ "disagree" on the item "Maintaining control in a classroom with inclusive students is not more difficult than maintaining control in a classroom without mainstreaming students.". 55.3\% of the students stated "agree" and $27.1 \%$ "strongly agree" on the expression "The inclusion of students with special education needs is not harmful to the language and mental development of normal students in the classroom." (Table 2).

Table 2: Frequency and percentage values of pre-service teachers' views on "Teacher's Competence" sub-dimension

\begin{tabular}{|l|c|c|c|c|c|c|c|c|}
\hline \multirow{2}{*}{ Items } & \multicolumn{2}{|c|}{$\begin{array}{c}\text { Strongly } \\
\text { disagree }\end{array}$} & \multicolumn{2}{c|}{ Disagree } & \multicolumn{2}{|c|}{ Agree } & \multicolumn{2}{c|}{$\begin{array}{c}\text { Strongly } \\
\text { agree }\end{array}$} \\
\cline { 2 - 10 } & $\mathrm{F}$ & $\%$ & $\mathrm{~F}$ & $\%$ & $\mathrm{~F}$ & $\%$ & $\mathrm{~F}$ & $\%$ \\
\hline $\begin{array}{l}\text { Special attention given to the student who } \\
\text { needs special education in the regular }\end{array}$ & 34 & 16,2 & 101 & 48,1 & 64 & 30,5 & 11 & 5,2 \\
\hline
\end{tabular}




\begin{tabular}{|l|c|c|c|c|c|c|c|c|}
\hline \hline $\begin{array}{l}\text { classroom will be to the detriment of other } \\
\text { students. }\end{array}$ & & & & & & & \\
\hline $\begin{array}{l}\text { Maintaining control in a classroom with } \\
\text { inclusive students is not more difficult than } \\
\text { maintaining control in a classroom without } \\
\text { mainstreaming students. }\end{array}$ & 19 & 9,0 & 79 & 37,6 & 86 & 41,0 & 26 & 12,4 \\
\hline $\begin{array}{l}\text { The inclusion of students with special } \\
\text { education needs is not harmful to the language } \\
\text { and mental development of normal students in } \\
\text { the classroom. }\end{array}$ & 6 & 2,9 & 33 & 15,7 & 114 & 54,3 & 57 & 27,1 \\
\hline
\end{tabular}

The data obtained from the analysis made for the "Benefits of Inclusion" sub-dimension of the data collection tool are presented in Table 3. For the expression "It would be better for children with special needs to live and be educated in special communities.", 33.8\% of the students stated "agree", 30\% "disagree" and 29.5\% "strongly agree". $51.4 \%$ of the students stated "disagree" and 25.7\% "agree" on the item "It is almost impossible for children with special needs to receive education in environments where normal children receive an education.". 55.2\% of the students stated "strongly agree" and 39\% " agree" on the expression "Having a special education student in the classroom helps normal students learn to respect differences.". $60 \%$ of the students said "agree" and $28 \%$ "strongly agree" to the item "The inclusion of students with special education needs is beneficial for the social development of normal students in the classroom.". 53.3\% of the students answered "The student with special education needs should be given every opportunity to participate in all activities in the regular classroom." as "agree" and 38.1\% "strongly agree" (Table 3).

Table 3: Frequency and percentage values of pre-service

teachers' views on "Benefits of Inclusion" sub-dimension

\begin{tabular}{|l|c|c|c|c|c|c|c|c|}
\hline \multirow{2}{*}{ Items } & \multicolumn{2}{|c|}{$\begin{array}{c}\text { Strongly } \\
\text { disagree }\end{array}$} & \multicolumn{2}{|c|}{ Disagree } & \multicolumn{2}{|c|}{ Agree } & \multicolumn{2}{|c|}{$\begin{array}{c}\text { Strongly } \\
\text { agree }\end{array}$} \\
\cline { 2 - 10 } & $\mathrm{F}$ & $\%$ & $\mathrm{~F}$ & $\%$ & $\mathrm{~F}$ & $\%$ & $\mathrm{~F}$ & $\%$ \\
\hline $\begin{array}{l}\text { It would be better for children with special } \\
\text { needs to live and be educated in special } \\
\text { communities. }\end{array}$ & 14 & 6,7 & 63 & 30,0 & 71 & 33,8 & 62 & 29,5 \\
\hline $\begin{array}{l}\text { It is almost impossible for children with } \\
\text { special needs to receive education in } \\
\text { environments where normal children receive } \\
\text { an education. }\end{array}$ & 29 & 13,8 & 108 & 51,4 & 54 & 25,7 & 19 & 5,0 \\
\hline $\begin{array}{l}\text { Having a special education student in the } \\
\text { lassroom helps normal students learn to } \\
\text { respect differences. }\end{array}$ & 2 & 1,0 & 10 & 4,8 & 82 & 39,0 & 116 & 55,2 \\
\hline $\begin{array}{l}\text { The inclusion of students with special } \\
\text { education needs is beneficial for the social } \\
\text { development of normal students in the } \\
\text { lassroom. }\end{array}$ & 2 & 1,0 & 23 & 11,0 & 126 & 60,0 & 59 & 28,0 \\
\hline $\begin{array}{l}\text { The student with special education needs } \\
\text { should be given every opportunity to }\end{array}$ & 6 & 2,9 & 12 & 5,7 & 112 & 53,3 & 80 & 38,1 \\
\hline
\end{tabular}


participate in all activities in the regular

classroom.

The data obtained from the analysis made for the "Sufficiency of Disabled Student" subdimension of the data collection tool are presented in Table 4. For the expression "There should be special schools for children who need special education.", 51.4\% of the students stated "strongly disagree" and 24.3\% "disagree". 49\% of the students stated "disagree" and $30 \%$ "strongly disagree" on the item "Children who need special education can never establish the social communication that normal children establish with each other." (Table 4).

Table 4: Frequency and percentage values of pre-service teachers' views on "Sufficiency of Disabled Student" sub-dimension

\begin{tabular}{|l|c|c|c|c|c|c|c|c|}
\hline \multirow{2}{*}{ Items } & \multicolumn{2}{|c|}{$\begin{array}{l}\text { Strongly } \\
\text { disagree }\end{array}$} & \multicolumn{2}{|c|}{ Disagree } & \multicolumn{2}{|c|}{ Agree } & \multicolumn{2}{|c|}{$\begin{array}{c}\text { Strongly } \\
\text { agree }\end{array}$} \\
\cline { 2 - 9 } & $\mathrm{f}$ & $\%$ & $\mathrm{f}$ & $\%$ & $\mathrm{f}$ & $\%$ & $\mathrm{f}$ & $\%$ \\
\hline $\begin{array}{l}\text { There should be special schools for children } \\
\text { who need special education. }\end{array}$ & 108 & 51,4 & 51 & 24,3 & 22 & 10,5 & 29 & 13,8 \\
\hline $\begin{array}{l}\text { Children who need special education can } \\
\text { never establish the social communication that } \\
\text { normal children establish with each other. }\end{array}$ & 63 & 30,0 & 103 & 49,0 & 34 & 16,2 & 10 & 4,8 \\
\hline
\end{tabular}

The data obtained from the analysis made for the "Negative Effect of Inclusion" subdimension of the data collection tool are presented in Table 5. For the expression "Being in the regular classroom accelerates the development of the student who needs special education.", $43.8 \%$ of the students stated "agree" and $34.3 \%$ "disagree". $45.2 \%$ of the students stated "disagree" and 33.3\% "agree" on the item "The inclusion of students with special needs does not require significant changes to the regular classroom setting." (Table 5).

Table 5: Frequency and percentage values of pre-service teachers' views on "Negative Effect of Inclusion" sub-dimension

\begin{tabular}{|l|c|c|c|c|c|c|c|c|}
\hline \multirow{2}{*}{ Items } & \multicolumn{2}{|c|}{$\begin{array}{c}\text { Strongly } \\
\text { disagree }\end{array}$} & \multicolumn{2}{|c|}{ Disagree } & \multicolumn{2}{|c|}{ Agree } & \multicolumn{2}{|c|}{$\begin{array}{c}\text { Strongly } \\
\text { agree }\end{array}$} \\
\cline { 2 - 10 } & $\mathrm{f}$ & $\%$ & $\mathrm{f}$ & $\%$ & $\mathrm{f}$ & $\%$ & $\mathrm{f}$ & $\%$ \\
\hline $\begin{array}{l}\text { Being in the regular classroom accelerates the } \\
\text { development of the student who needs special } \\
\text { education. }\end{array}$ & 16 & 7,6 & 72 & 34,3 & 92 & 43,8 & 30 & 14,3 \\
\hline $\begin{array}{l}\text { The inclusion of students with special needs } \\
\text { does not require significant changes to the } \\
\text { regular classroom setting. }\end{array}$ & 36 & 17,1 & 95 & 45,2 & 70 & 33,3 & 9 & 4,3 \\
\hline
\end{tabular}

In order to determine whether there is a relationship between the factors of the measurement tool, the correlation coefficient was calculated using the Pearson correlation and the findings are presented in Table 6. According to the data presented in Table 6, a positive correlation of 0.05 was found between Factor 1 and Factor 2, between 
Factor 2 and Factor 3 and Factor 4, between Factor 3 and Factor 4, and between Factor 4 and Factor 5. A positive correlation of 0.01 level was found between Factor 1 and Factor 5 (Table 6).

Table 6: Relationship levels between the factors of the scale

\begin{tabular}{|l|c|c|c|c|c|}
\hline Factor & Factor 1 & Factor 2 & Factor 3 & Factor 4 & Factor 5 \\
\hline Factor 1 & 1 & $0,172^{*}$ & $0,306^{* *}$ & $0,253^{* *}$ & 0,003 \\
\hline Factor 2 & $0,172^{*}$ & 1 & $0,168^{*}$ & $0,137^{*}$ & $0,250^{* *}$ \\
\hline Factor 3 & $0,306^{* *}$ & $0,168^{*}$ & 1 & $0,155^{*}$ & 0,063 \\
\hline Factor 4 & $0,253^{* *}$ & $0,137^{*}$ & $0,155^{*}$ & 1 & $0,167^{*}$ \\
\hline Factor 5 & 0,003 & $0,250^{* *}$ & 0,063 & $0,167^{*}$ & 1 \\
\hline
\end{tabular}

\section{Discussion}

The survey model was used in this study, which aimed to quantitatively evaluate the views of pre-service teachers on inclusive education. The findings obtained from the research are discussed below with the relevant literature.

When the views of the pre-service teachers on the "Management of the Inclusion Class" and "Opinions on Inclusion" sub-dimensions are examined, it is seen that they have positive opinions in 5 items and negative opinions in 3 items. Pre-service teachers stated that expectations from children should change according to whether they have special needs or not, and that the probability of children with special needs showing behavioral problems is independent of the type of classroom they are educated in. Preservice teachers also hold the view that inclusion eliminates the differences between students, helps students gain independence, and does not negatively affect their normally developing peers. There are studies supporting this finding in the literature (Cerezci, 2015; Erdagi, 2019; Gok, 2009; Kim \& Cho, 2008). Cerezci (2015) aimed to evaluate the inclusive education practices in pre-school education institutions in terms of inclusion criteria. Case study, one of the qualitative research methods, was used in the research. "Evaluation Forms for Inclusive Education in Pre-School Period" prepared by the researcher were used. 45 teachers, 22 school principals, 49 parents and 55 children with special needs participated in the study. According to the results of the research, the teachers stated that inclusive education provided the most benefits to students with special needs in language and social development areas, while there was no improvement in cognitive and motor development areas. Gok (2009) aimed to determine the views and suggestions of preschool teachers about inclusion. According to the results of the research, teachers emphasized that students with special needs and students with normal development support each other's development. They stated that the cooperation of students with special needs, their level of adaptation to school and their social skills increased, their cognitive and language development accelerated, and their self-care and manual skills improved. According to the results of the research, in which Erdagi (2019) aimed to determine the views of classroom teachers on inclusive education and to 
develop suggestions for a more effective inclusive education, the majority of teachers stated that inclusive education practices had a positive effect on students with special needs.

According to the findings of the study, pre-service teachers stated that they would be happier if the individuals with special needs were separated, and that individuals with special needs could and would experience chaos in normal classrooms. When the relevant literature is examined, it is seen that there are studies that overlap with these findings (Demir \& Acar, 2011; Erdagi, 2019; Kose, 2018; Mertoglu, 2018; Sarac \& Colak, 2012; Sekercioglu, 2010; Unal, 2010; Unal \& Saban. 2014). In the study carried out by Erdağ 1 (2019), when the answers given by the teachers regarding the additional situations that inclusive education brings to the teachers are examined, it has been determined that the teachers' encounter with problem behaviors in classroom management is quite high. According to the findings obtained in the study by Unal and Saban (2014), in which the attitudes of teachers working in inclusive classrooms towards inclusive education were examined, $7.5 \%$ of the teachers stated that students with special needs disrupted the classroom order, while $48.75 \%$ stated that they partially disrupted the classroom order. Kose (2018) aimed to examine and determine the attitudes of teachers who teach inclusive education in their classrooms towards inclusive education. The sample of the study consisted of 258 teachers working in 36 primary and secondary schools in the province of Elazı ğ. According to the results of the research, the teachers stated that the inclusion of students would distract the students with normal development, disrupt the classroom discipline, they were more likely to do undesirable behaviors, and that they were more harmful to other students, and that it was more beneficial for these students to receive segregated education in special classes. In the study conducted by Unal (2010), it was aimed to determine the attitudes of teachers, normally developing students and parents towards mainstreaming. According to the results of the research, $7.5 \%$ of the teachers stated that the class level of the students with special needs was disrupted, and $48.5 \%$ of them partially disrupted the classroom order. Sekercioglu (2010) included 170 branch teachers in his study, which aims to identify the problems faced by primary school second-level branch teachers during inclusive education. The results of the research show that the majority of teachers stated that inclusive students are negatively affected by each other and negatively affect the classroom environment.

When the findings related to the "Teacher's Competence" sub-dimension were examined in the study, for the expression "Special attention given to the student who needs special education in the regular classroom will be to the detriment of other students.", 48.1\% of the students stated "disagree" and 30.5\% "agree". Also, 55.3\% of the students stated "agree" and 27.1\% "strongly agree" on the expression "The inclusion of students with special education needs is not harmful to the language and mental development of normal students in the classroom.". In the light of these findings, it can be said that pre-service teachers think that inclusiveness does not negatively affect students at the normal development level in terms of academic and social aspects. When the second item related to this sub-dimension is examined, it is seen that the pre-service teachers think that the presence of inclusive students in the classroom does not affect 
classroom control (41\% agree and $12.4 \%$ strongly agree). There are studies supporting these results in the literature (Gok, 2009; Unal, 2010; Erdagi, 2019). When the answers given by the pre-service teachers regarding the "Benefits of Inclusion" sub-dimension are examined, it is seen that inconsistent results emerge. When these inconsistent results are examined, it can be said that the knowledge and skill levels of teacher candidates for individuals with special needs and inclusion practice are not sufficient. There are studies in the literature that support this view (Batu, Kircaali-Iftar \& Uzuner, 2004; Gok, 2009; Unal, 2010; Sadioglu, 2011; Bozarslan \& Batu, 2014; Batu et al., 2017). Batu et al. (2017) aimed to determine the views of preschool teachers about inclusion in their study. 45 preschool teachers participated in the research. According to the results of the research, whose data were collected with a semi-structured interview form, it was determined that the most frequently mentioned problem ( $f=19)$ among the main problems in inclusive education in pre-school education was lack of knowledge and experience. The aim of Sadioglu's (2011) research is to determine the problems, opinions and suggestions experienced by classroom teachers working in seven different regions of Turkey during the inclusive education process. The descriptive method, one of the qualitative research methods, was used in the research and the data were collected with a semi-structured interview form. The study group of the research consisted of 23 classroom teachers. The results of the research show that teachers' knowledge and skills about inclusive education practices are insufficient and they need training on the subject.

\section{Conclusion}

Although the results of the research are generally positive, the opinions of the pre-service teachers about inclusive education are inconsistent with each other, indicating that the knowledge and skill levels of the pre-service teachers about students with special needs are insufficient. It is important for a qualified inclusive education that teacher candidates who will start working in schools in the future develop positive attitudes towards inclusive education and have high levels of knowledge and skills. In this direction, it can be ensured that pre-service teachers take new lessons that they can practice with students with special needs in addition to the special education lesson during the undergraduate period. In addition, teaching practice can be done in schools where inclusive education is practised.

\section{Limitations}

This study is limited in many ways. The effects of the demographic and socio-economic status of prospective teachers and parents are excluded. Many educators believe that these factors can interact, influencing prospective teachers' learning outcomes. The sample size is another limiting factor.

\section{Conflict of interest statement}

The authors declare no conflicts of interests. 


\section{About the Authors}

Dr. Suat Turkoguz is an associate professor at Science Education Department, Buca Faculty of Education, Dokuz Eylul University, Turkey. His areas of expertise include Science Education and Chemistry Education.

Muhammet Sait Baran (M.Sc.) is a research assistant at Special Education Department, Faculty of Education, Usak University, Turkey. His areas of expertise include Special Education, Mental Disabilities and Family Education.

Mehmet Gurbuz (M.Sc.) is a research assistant at Special Education Department, Faculty of Education, Usak University, Turkey. His areas of expertise include Special Education, Mental and Learning Disabilities.

Dr. Cengiz Tuysuz is an associate professor at Science Education Department, Faculty of Education, Usak University, Turkey. His areas of expertise include Science Education and Chemistry Education.

Dr. Ilker Ugulu is an associate professor at Special Education Department, Faculty of Education, Usak University, Turkey. His areas of expertise include Gifted Education, Biology Education, Environmental Education and Ecology.

\section{References}

Ainscow, M., \& Miles, S. (2008). Making education for all inclusive: where next? Prospects, $38,15-34$.

AlMahdi, O., \& Bukamal, H. (2019). Pre-Service Teachers' Attitudes Toward Inclusive Education During Their Studies in Bahrain Teachers College. Sage Open Journal, 114.

Al-Zyoudi, M. (2006). Teachers' Attitudes Towards Inclusive Education in Jordanian Schools. International Journal of Special Education, 21(2), 55-62.

Antonak, R. F., \& Larrivee, B. (1995). Psychometric analysis and revision of the opinions relative to mainstreaming scale. Exceptional children, 62(2), 139-149.

Avramidis, E., Bayliss, P., \& Burden, R. (2000). A Survey into Mainstream Teachers' Attitudes Towards the Inclusion of Children with Special Educational Needs in the Ordinary School in one Local Education Authority. Educational Psychology, 20(2), 191-211.

Avsar-Tuncay, A., \& Kizilaslan, A. (2021). Pre-service teachers' sentiments, attitudes and concerns about inclusive education in Turkey. European Journal of Special Needs Education, DOI: 10.1080/08856257.2021.1873524.

Aydin, H., Yorek, N. \& Ugulu, I. (2015). An investigation of some variables related students' attitudes towards performance assignments. Mustafa Kemal University Journal of Graduate School of Social Sciences, 12(31), 211-229.

Batu, S., Kircaali-İftar, G., Uzuner, Y. (2004). Özel gereksinimli öğrencilerin kaynaştırıldığı bir kız meslek lisesindeki öğretmenlerin kaynaştırmaya ilişkin görüş ve önerileri. Ankara Üniversitesi Ĕ̆itim Bilimleri Fakültesi Özel Ĕ̆itim Dergisi, 5(2), 33-50. 
Batu, E. S., Odluyurt, S., Alagozoglu, E., Cattik, M. \& Sahin, S. (2017). Determining the opinions of preschool teachers regarding inclusion. Ankara Üniversitesi Ĕgitim Bilimleri Fakültesi Özel Eğitim Dergisi, 18(3), 401-420.

Bozarslan, B., \& Batu, E. S. (2014). Özel anaokullarında çalışan eğiticilerin okulöncesi dönemde kaynaştırma ile ilgili görüş ve önerileri. Abant İzet Baysal Üniversitesi Ĕ̆itim Fakültesi Dergisi, 14(2), 86-108.

Cankaya, O., \& Korkmaz, I. (2012). İlköğretim I. kademede kaynaştırma eğitimi uygulamalarının sınıf öğretmenlerinin görüşlerine göre değerlendirilmesi. Ahi Evran Üniversitesi Kırşehir Ĕ̆itim Fakültesi Dergisi, 13(1), 1-16.

Cerezci, Ö. (2015). Okul öncesi eğitim kurumlarında yapılan kaynaştırma eğitimi uygulamalarının kaynaştırma kriterleri açısından değerlendirilmesi. Yüksek Lisans Tezi. Gazi Üniversitesi Eğitim Bilimleri Enstitüsü, Ankara.

De Boer, A., Pijl, S. P., \& Minnaert, A. (2011). Regular primary school teachers' attitudes towards inclusive education: a review of the literature. International Journal of Inclusive Education, 15(3), 331-353.

Demir, M. K., \& Acar, S. (2011). Kaynaştırma Eğitimi Konusunda Tecrübeli Sınıf Öğretmenlerinin Görüşleri. Kastamonu Eğitim Dergisi, 19(3), 719-732.

Ediyanto, R. M., Atika, I. A., \& Kawai, N. (2020). The Pre-Service Teachers' Attitudes Towards Inclusive Education: An Empirical Study in Yogyakarta City, Indonesia. Discourse and Communication for Sustainable Education, 11(1), 65-73.

Erdagi, İ. (2019). Sını öğretmenlerinin kaynaştırma ĕ̆itimine ilişkin görüşlerinin incelenmesi. Yüksek Lisans Tezi. Kafkas Üniversitesi Sosyal Bilimler Enstitüsü, Kars.

Erkol, S. \& Ugulu, I. (2014). Examining biology teachers candidates' scientific process skill levels and comparing these levels in terms of various variables. Procedia Social and Behavioral Sciences, 116: 4742-4747. http://dx.doi.org/10.1016/j.sbspro.2014.01.1019

Ewing, D. L., Monsen, J. J., \& Kielblock, S. (2017). Teachers' attitudes towards inclusive education: a critical review of published questionnaires. Educational Psychology in Practice, 1-15.

Gok, G. (2009). Okulöncesi eğitimi öğretmenlerinin kaynaştırma eğitimine ilişkin görüşleri ve önerileri. Yüksek Lisans Tezi. Erciyes Üniversitesi Sosyal Bilimler Enstitüsü, Kayseri.

Gurgur, H., \& Hasanoglu Yazcayir, G. (2019). Türkiye' de kaynaştırma eğitimine yönelik öğretmenlerin görüşlerine odaklanılmış lisansüstü eğitim tezlerinin sentezlenmesi: meta-etnografik bir çalışma. Eğitimde Nitel Araştırmalar Dergisi, 7(2), 845-872.

Hind, K., Larkin, R., \& Dunn, A. K. (2019) Assessing Teacher Opinion on the Inclusion of Children with Social, Emotional and Behavioural Difficulties into Mainstream School Classes. International Journal of Disability, Development and Education, 66(4), 424-437.

Ince, S. (2012). Preschool teacher candidate's attitudes and concerns about inclusive education taking into consideration whether they took special courses or not at university. International Journal of Early Childhood Education Research, 1(3), 1-19. 
Killoran, I., Woronko, D., \& Zaretsky, H. (2014). Exploring preservice teachers' attitudes towards inclusion. International Journal of Inclusive Education, 18(4), 427-442.

Kim, J. H. \& Cho, Y. T. (2008). Qualitative research on the recognition of kindergarten teachers on effects of inclusive education of the disabled infants. Korean Journal Inclusive Education, 3, 27-44.

Kircaali-Iftar, G. (1996). Kaynaştırmaya İlişkin Görüşler Ölçeği'nin geçerlik ve güvenirlik bulguları (The psychometric characteristics of the Turkish version of Opinions Relative to Integration of Students with Disabilities). 6. Özel Eğitim Günleri Poster Bildirisi, Hacettepe Üniversitesi, Ankara, Türkiye.

Koruoglu, N., Ugulu, I. \& Yorek, N. (2015). Investigation of High School Students' Environmental Attitudes in Terms of Some Demographic Variables. Psychology, 6: 1608-1623. http://dx.doi.org/10.4236/psych.2015.613158

Kose, A. (2018). Sınıf ve branş öğretmenlerinin kaynaştırma öğrencilerine yönelik tutumlarının incelenmesi. Yüksek Lisans Tezi. Fırat Üniversitesi Eğitim Bilimleri Enstitüsü, Elazı̆̆.

McHatton, P. A., \& McCray, E. D. (2007). Inclination toward Inclusion: perceptions of elementary and secondary education teacher candidates. Action in Teacher Education, 29(3), 25-32.

Mertoğlu, H. (2018). Öğretmen adaylarının kaynaştırmaya ilişkin tutumlarının öğretim stilleri ve bazı değişkenler açısından incelenmesi. Kesit Akademi Dergisi, 4(14), $127,152$.

Orel, A., Zerey, Z., \& Toret, G. (2004). Sınıf öğretmeni adaylarının kaynaştırmaya yönelik tutumlarının incelenmesi. Ankara Üniversitesi Ĕ̆itim Bilimleri Fakültesi Özel Ĕ̆itim Dergisi, 5(1), 23-33.

Sadioglu, O. (2011). Stnıf öğretmenlerinin kaynaştırmaya ilişkin sorunları, beklentileri ve önerilerine yönelik nitel bir araştırma. Doktora Tezi. Uludağ Üniversitesi Eğitim Bilimleri Enstitüsü, Bursa.

Sarac, T. \& Colak, A. (2012). Kaynaştırma uygulamaları sürecinde ilköğretim sınıf öğretmenlerinin karşılaştıkları sorunlara ilişkin görüş ve önerileri. Mersin Üniversitesi Ĕ̆itim Fakültesi Dergisi, 8(1), 13-28.

Sart, H., Ala, H., Yazlık, O. \& Yılmaz, F. K. (2004). Türkiye Kaynaştırma Eğitiminde Nerede?: Eğitimciye Öneriler. XIII. Ulusal Eğitim Bilimleri Kurultayı, 6-9 Temmuz 2004 İnönü Üniversitesi, Eğitim Fakültesi, Malatya.

Sekercioglu, B. (2010). İlköğretim II. Kademe branş öğretmenlerinin kaynaştırma uygulamalarında karşılaştıkları sorunlar ile ilgili görüşleri. Yüksek Lisans Tezi. Gazi Üniversitesi Eğitim Bilimleri Enstitüsü, Ankara.

Topcu, E., \& Katılmıs, A. (2013). Yarı zamanlı kaynaştırma eğitimi alan ortaokul öğrencilerinin sosyal bilgiler dersine yönelik düşünceleri. Sakarya University Journal of Education, 3(3), 48-81.

Tuysuz, C. \& Ugulu, I. (2021). Determination of the satisfaction levels of prospective teachers regarding the e-learning application during the coronavirus pandemic. European Journal of Education Studies, $8 \quad$ (3): 199-134. http://dx.doi.org/10.46827/ejes.v8i3.3623 
Ugulu, I., Aydin, H., Yorek, N. \& Dogan, Y. (2008). The impact of endemism concept on environmental attitudes of secondary school students. Natura Montenegrina, 7 (3): 165-173.

Ugulu, I. (2009). Determination of retention of students' knowledge and the effect of conceptual understanding. Biotechnology \& Biotechnological Equipment, 23(1): 14-18.

Ugulu, I., Sahin, M., \& Baslar, S. (2013). High school students' environmental attitude: Scale development and validation. International Journal of Educational Sciences, 5(4): 415-424.

Ugulu, I. (2013). Confirmatory factor analysis for testing validity and reliability of traditional knowledge scale to measure university students' attitudes. Educational Research and Reviews, 8 (16): 1399-1408.

Ugulu, I. \& Erkol, S. (2013). Environmental attitudes of biology teacher candidates and the assessments in terms of some variables. NWSA-Education Sciences, 8(1): 79-89.

Ugulu, I., Akkaya, Z. \& Erkol, S. (2013). An investigation on environmental attitudes of gifted students and the assessments in terms of some demographic variables. NWSA-Education Sciences, $\quad$ 8(4): 400-410. http://dx.doi.org/10.12739/NWSA.2013.8.4.1C0595

Ugulu, I. (2015a). A quantitative investigation on recycling attitudes of gifted/talented students. Biotechnology \& Biotechnological Equipment, 29: 20-26. http://doi.org/10.1080/13102818.2015.1047168

Ugulu, I. (2015b). Development and validation of an instrument for assessing attitudes of high school students about recycling. Environmental Education Research, 21(6): 916942. http://doi.org/10.1080/13504622.2014.923381

Ugulu, I., Yorek, N., Baslar, S. (2015). The effect of recycling education on high school students' conceptual understanding about ecology: A study on matter cycle. Educational Research and Reviews, 10(16): 2207-2215. http://dx.doi.org/10.5897/ERR2015. 2386

Ugulu, I. (2019). Efficacy of recycling education integrated with ecology course prepared within the context of enrichment among gifted students. International Journal of Educational Sciences, 26(1-3), 49-58. https://doi.org/10.31901/24566322.2019/26.1$\underline{3.1086}$

Ugulu, I. (2020). Gifted students' attitudes towards science. International Journal of Educational Sciences, 28(1-3). 7-14. https://doi.org/10.31901/24566322.2020/28.1$\underline{3.1088}$

Ugulu, I. (2021a). Special Education Teachers' Attitudes Towards the Environment. International Journal of All Research Education and Scientific Methods, 9(6): 1376-1381.

Ugulu, I. (2021b). Recycling Attitudes of Prospective Special Education Teachers. International Journal of All Research Education and Scientific Methods, 9(6): 1574-1578.

Unal, F. (2010). Kaynaştırma uygulamasının yapıldı̆̆ı sınıflarda öğretmen, normal gelişim gösteren öğrenci ve engelli öğrenci velilerinin kaynaştırmaya yönelik tutumları. Yüksek Lisans Tezi. Çukurova Üniversitesi Sosyal Bilimler Enstitüsü, Adana. 
Unal, F. \& Iflazoglu Saban, A. (2014). Kaynaştırma uygulamasının yapıldığı sınıflarda, öğretmenlerin kaynaştırmaya yönelik tutumları-I. Çukurova Üniversitesi Sosyal Bilimler Enstitüsü Dergisi, 23(1), 388-405.

Yazıcıoglu, T. (2018). Kaynaştırma uygulamalarının tarihsel süreci ve Türkiye'de uygulanan kaynaştırma modelleri. Nevşehir Hacı Bektaş Veli Üniversitesi SBE Dergisi, 8(1), 92-110.

Yorek, N., Aydin, H., Ugulu, I., \& Dogan, Y. (2008). An Investigation on Students' Perceptions of Biodiversity. Natura Montenegrina, 7 (3), 175-184.

Yorek, N., Ugulu, I., \& Aydin, H. (2016). Using self-organizing neural network map combined with ward's clustering algorithm for visualization of students' cognitive structural models about aliveness concept. Computational Intelligence and Neuroscience, Article ID 2476256, 1-14. http://dx.doi.org/10.1155/2016/2476256

Yorek, N., Ugulu, I., Sahin, M. \& Dogan, Y. (2010). A qualitative investigation of students' understanding about ecosystem and its components. Natura Montenegrina, 9 (3): 973-981.

Yorek, N., Sahin, M. \& Ugulu, I. (2010). Students' representations of the cell concept from 6 to 11 grades: Persistence of the "fried-egg model". International Journal of Physical Sciences, 5(1): 15-24.

Yorek, N. \& Ugulu, I. (2015). A CFBPN artificial neural network model for educational qualitative data analyses: Example of students' attitudes based on Kellerts' typologies. Educational Research and Reviews, 10(18): 2606-2616. http://dx.doi.org/10.5897/ERR2015.2370. 
Suat Turkoguz, Muhammet S. Baran, Mehmet Gurbuz, Cengiz Tuysuz, Ilker Ugulu QUANTITATIVE EVALUATION OF PROSPECTIVE TEACHERS' VIEWS ON INCLUSIVE EDUCATION

Creative Commons licensing terms

Author(s) will retain the copyright of their published articles agreeing that a Creative Commons Attribution 4.0 International License (CC BY 4.0) terms will be applied to their work. Under the terms of this license, no permission is required from the author(s) or publisher for members of the community to copy, distribute, transmit or adapt the article content, providing a proper, prominent and unambiguous attribution to the authors in a manner that makes clear that the materials are being reused under permission of a Creative Commons License. Views, opinions and conclusions expressed in this research article are views, opinions and conclusions of the author(s). Open Access Publishing Group and European Journal of Education Studies shall not be responsible or answerable for any loss, damage or liability caused in relation to/arising out of conflicts of interest, copyright violations and inappropriate or inaccurate use of any kind content related or integrated into the research work. All the published works are meeting the Open Access Publishing requirements and can be freely accessed, shared, modified, distributed and used in educational, commercial and non-commercial purposes under a Creative Commons Attribution 4.0 International License (CC BY 4.0). 